Economica: Jurnal Ekonomi Islam - Volume 11, Nomor 2 (2020): 285 - 307

ISSN: 2085-9325 (print); 2541-4666 (online)

DOI: https://doi.org/10.21580/economica.2020.11.2.4374

\title{
Determinant Market Power of Sharia Banking in Indonesia
}

\author{
Muchamad Fauzi \\ Universitas Islam Negeri Walisongo Semarang, Indonesia \\ email: muchamad.fauzi@walisongo.ac.id
}

\begin{abstract}
This study aims to analyze the level of market power and determinants of Sharia banking in Indonesia, using the Bresnahan-Lau model approach. This study is explanatory research using a quantitative approach. The data used are secondary, including one dependent variable, namely Market Power (MP), with five independent variables, namely Equivalent Rate (ER), 3month Bank Indonesia Syariah Certificates (SBIS3), Number of Branches (CAB), Gross Domestic Product (GDP) ), Inflation (INF), and one control variable that is the historical aspect (MPt-1) by using time series data on the annual financial statements of Bank Syariah Mega Indonesia (BSMI), Bank Syariah Mandiri (BSM), Bank Muamalat Indonesia (BMI). The results show market power in the Sharia banking industry in Indonesia, with a significance level of ER and GDP interaction testing of 0,000 .
\end{abstract}

Keywords: Market Power; Equivalent Rate; SBIS3; CAB; PDB; INF

\begin{abstract}
Abstrak: Penelitian ini bertujuan untuk menganalisis tingkat market power serta determinan market power perbankan syariah di Indonesia, dengan menggunakan pendekatan Bresnahan-Lau model. Penelitian ini merupakan penelitian explanatory research menggunakan pendekatan kuantitatif. Sumber data yang digunakan adalah data sekunder, meliputi satu variabel tergantung yaitu Market Power (MP), dengan lima variabel bebas yaitu Equivalent Rate (ER), Surat Berharga Indonesia Syariah 3bulan (SBIS3), Jumlah Cabang (CAB), Produk Domestik Bruto (PDB), Inflasi (INF), serta 1 variabel kontrol yaitu aspek historis (MPt-1). menggunakan data time series laporan keuangan tahunan Bank Syariah Mega Indonesia (BSMI), Bank Syariah Mandiri (BSM), Bank Muamalat Indonesia (BMI). Hasilnya menunjukkan bahwa terdapat market power pada industri syariah banking yang berkedudukan di Indonesia dengan tingkat signifikansi pengujian interaksi ER dan PDB sebesar 0,000.
\end{abstract}

Kata Kunci: Market Power; Equivalent Rate; SBIS3; CAB; PDB; INF

Economica: Jurnal Ekonomi Islam - Volume 11, Nomor 2 (2020) 


\section{Introduction}

Sharia Banking financial institutions in Indonesia were established in the 90s with the enactment of Law no. 7 of 1992, and then renewed in 1998 with Law no. 10, in the form of a bank regarding anti-usury, namely the profitsharing model (Antonio 2001). Thus, the development of Sharia banking is relatively rapid, which began with the operation of Bank Muamalat and then Bank Syariah Mandiri (BSM). BSM is a business unit of Bank Mandiri with separate legal entities and branches under the management of conventional banks, including BNI Syariah, BRI Syariah, Bank IFI Syariah, Bank Danamon Syariah, Bank Mega Syariah, Bank Bukopin, BII and HSBC (Yafie 2003).

Based on its growth, Sharia banking should help reduce poverty because the purpose of Sharia banks is to meet the community's needs as marginal economic actors, by applying interest-free financing and without guarantees of certificates or commercial papers. Sharia banking capabilities have been tested in dealing with the monetary crisis (Theis 2016). It can be said that Sharia banking is more natural and very relevant for the management of the people's social funds from zakat, infaq funds, alms funds, and social funds sourced from operational results (qardh).

Then from the financial aspect, it can be seen that in 2009 the total financing of Sharia banking amounted to Rp11,490 billion. There was a very significant growth of Rp147,505 billion in 2017. In terms of FDR, from 2009 to 2013 , FDR consecutively increased from $96.86 \%$ to $103.64 \%$ but decreased in 2014-2016 to 88.94\%. However, it rose again in 2017 to $100 \%$, showing the increasing number of funds distributed by Sharia banking. The NPF ratio fluctuated during 2009-2017, slightly increased (worsen) from 2.35\% in 2009 to $4.75 \%$ in 2011 and decreased (improved) in 2012 and 2013 to $3.95 \%$. It increased (worsen) again in 2014 at $4.01 \%$ but could be handled well as seen from the decline in NPF at the end of 2017 to $2.22 \%$, indicating the quality of Sharia bankings financing is getting better. 
One of the best economic indicators in evaluating economic growth for a country is to assess GDP (Gross Domestic Product). As stated by (Samuelson and Nordhaus 2009), GDP is the total output produced within the boundaries of a country's territory for one year. To calculate this national income, the macro measurement that describes the condition of a country is used. In general, this is done by comparing conditions between countries by looking at their national income to provide an overview for the World Bank so that it can be considered to determine whether a country is in the developed or developing category based on its GDP income.

Meanwhile, another determinant that prevents the rate of economic growth is inflation. Inflation is defined as an overall increase in the amount of money that must be paid immediately for goods and services (Greenwald and Pratkanis, 1984). Inflation can reduce the motivation to save and attitudes towards people's desire to save. If this is not immediately addressed, it will decrease the collection of funds obtained by Sharia banks. Inflation in December 2012 was 4.30\%, and it increases 5.90\% by March 2013, which was the highest inflation since 2012.

In this case, competitiveness becomes a force that determines the success or failure of companies in specific industries. If it continues to operate, but its competitiveness is low, competitors will threaten the existence of Sharia banks in the banking industry. Therefore, looking at the current competitive conditions reminds us of the need for an acceleration program so that Sharia banking can push the slow development of conventional banks.

To find out the actual strength of Sharia banking can be carried out by testing its market power. Market power is a performance measurement that can show how much the company can raise the price higher than marginal costs (Church and Ware 2000). If it is related to market structure, and the company is in a perfectly competitive market, it certainly does not have market power. In contrast, if the company is in a monopoly market, it will have the greatest level of market power. The more competitive a market is, the 
lower the market power it has. On the contrary, the more uncompetitive the market is, the market power in that market will show a higher level.

There are two approaches to measure market power: the Structure Conduct Performance (SCP) approach and the Bresnahan Lau approach. This SCP approach is used to determine the good and bad performance of a market whose condition depends on the prevailing market structure model so that the market power obtained will be higher. The high market power can show an indication of the lower level of competition. Furthermore, the indication of the level of competition based on concentration becomes the basis for making the main hypothesis in studies based on the SCP approach.

The Bresnahan-Lau (BL) approach puts performance as a variable that can affect the market structure. Then the market structure can affect the company's behavior. This behavior can later affect the structure that occurs in the market (Prasetyo 2007). In the Bresnahan-Lau (BL) approach, the level of concentration is not an important factor used in determining market performance. When the market is perfectly competitive, prices usually reflect production costs even if only one firm is in the industry. This means that a concentrated industry will become very competitive if the barriers to entry of new competitors are low enough. Shaffer (1982) was the first to apply the BL model in the banking industry. Shaffer (1982) studied the banking industry in Canada using time series data as aggregate data for the banking sector and estimated the average level of competition during the observation period.

Shaffer (1982) researched banking in New York using the Breshanan-Lau model with 1989 data and found monopolistic competition behavior. With these results, he stated that there is no market power in the banking industry. Meanwhile, Kim, Lee, and Kim (2004) Kim, Lee, and Kim (2004) also tested market power in the banking industry in Korea. The result showed that banks have monopoly power, and banks compete in monopolistic competition conditions. With these results, Kim, Kim, Lee, and Kim (2004) concluded that 
there was no market power in the banking industry in Korea before and after the crisis.

Meanwhile, Kasri and Iman (2010), conducted a study by testing banking competition in Canada. This research on banking in Canada confirms Shaffer's research using the Bresnahan methodology, which rejects the monopoly power hypothesis. They found the existence of perfect competition behavior, which means that there is market power. They also found that market power was influenced by the interest rate, gross domestic product (GDP/GDP), and inflation variables.

Then, the research conducted by Biker and Haaf (2001) Kasri and Iman (2010) does not accept the hypothesis of a perfect competition market or a perfect cartel market (collusive oligopoly) for all markets. Instead, their findings confirm that banks operating on a small scale will be in a less competitive environment when compared to banks operating on a national or international scale.

Claessens and Laeven (2003); Kasri and Iman (2010) also tested market power by linking the competition between a country's banking sector with structural indicators and financial system policies. The results are consistent with Biker and Haaf; there is a low level of competition, as is the case in the United States. In addition, they also state that market power is influenced by interest rates, gross domestic product (GDP/GDP), and inflation.

The use of the BL methodology in research to test the market power of Islamic banking is still limited. One who studies Sharia banking is Abdul Majid et al. (2007) in Kasri and Iman (2010); the results of his study indicate that market power will be generated in conditions of monopolistic competition. Furthermore, it is concluded that the competitive behavior of banks is directly related to the number of banks and branch offices operating in the market. Again, Weill (2009) in Kasri and Iman (2010) uses the BL methodology and the performance and behavior structure (SCP) to make comparisons between 
Sharia banking and conventional banking models. By using data from conventional banking models and Sharia banking models for countries that have implemented a dual banking system, the results reveal no significant difference in market power, namely between Sharia banking and conventional banking models. In addition, Weill (2009) in Kasri and Iman (2010)also states that market power is determined by profit sharing, interest rate, GDP/GDP, inflation, and the number of branch offices.

Therefore, based on the above perspective, the existence of a theory gap and research gap, research questions that arise, and the weaknesses of previous studies regarding the measurement of the level of banking strength using the Structural Conduct Performance (SCP) approach, this study attempts to analyze the level of market power and market power determinants of Sharia banking in Indonesia by using the Bresnahan-Lau model approach.

The purpose of this study is to analyze the level of market power of Sharia banking in Indonesia and what factors (determinants) can affect market power, such as the Equivalent Rate (ER), 3-month Bank Indonesia Syariah Certificates (SBIS3), Number of Branches (CAB), Product Gross Domestic Product (GDP), and Inflation (INF).

\section{Literature review}

\section{Competition theory}

The market is defined as a group of buyers and a group of sellers who interact so that they can determine a product or a set of products (Pindyick and Rubinfeld 2013). With the existence of the market, competition and various forms of the market are created. The shape of the market affects the behavior of the company. Market forms that use different systems will have different impacts in determining prices, investment decisions, input decisions, and company behavior in responding to activities carried out by competitors in the industry. 


\section{The concept of competition in Islam}

Islamic economics allows the pattern of fulfilling personal needs in realizing efficiency and development but limits and restructures the achievement of personal goals by elaborating moral commands into the model by expanding the scope not only limited to the worldly aspect, which is transitional, to the eternal afterlife. Moral values can also help transform consumer tastes and preferences by limiting consumer spending, especially on primer necessities and necessities of life, to minimize luxury and extravagance (greed). This pattern of behavior, combined with zakat and other charitable expenditures, will contribute to better fulfillment of basic needs and increase the level of savings, investment and promote development (Chapra 2003).

The market mechanism requires that all competing parties in the market operate under the direction of the light and the moral values and control established by these values over self-interest and private property rights, to ensure fairness for all parties interacting in the market, both consumers and production factors (Chapra 2003). To this end, several Islamic scholars have emphasized the role of cooperation in Muslim societies without neglecting the important role of competition in the market system. The role of market mechanisms that are morally directed and supported by cooperation, the role of families and communities in ensuring mutual prosperity, and social solidarity will guarantee social interests that do not burden the market or the government alone.

\section{Islamic banking concept}

According to Law no. 21 of 2008 Regarding Sharia Banking, Sharia Bank is a bank that carries out its business activities based on Islamic sharia principles. Moreover, this has been described in the Blueprint on the Development of Indonesian Sharia Banking (Bank Indonesia, 2002). Islamic banking aims to achieve falah, meaning as a benefit that is oriented to the

Economica: Jurnal Ekonomi Islam - Volume 11, Nomor 2 (2020) https://journal.walisongo.ac.id/index.php/economica 
wider community. With the consequence of implementing the sharia principle, banks do not offer various derivative products like those that already exist and are carried out by the conventional banking system because there are speculative elements and the potential for gambling in them, even though the profits are big.

\section{Islamic banking market power}

Measurement of market power using two approaches. The first approach is the traditional SCP approach, which is based on accounting data related to profit and cost to measure market power. The second approach is the New Industrial Economics (NIE) approach, or the New Empirical Industrial Organization (NEIO), by reducing or eliminating the use of accounting data used to measure market power. Instead, the NIE approach uses a structural framework of the relationship between supply and demand to estimate market power. The basis of this approach is that companies in a perfectly competitive market system are price takers and companies in an imperfect market system whose conditions have market power and will have unequal reactions to exogenous changes in demand and supply (Church and Ware 2000).

\section{Previous research review}

In calculating the degree of competition, it is necessary to use the correct method proposed by Bresnahan (1989) in Demirel and Hatirli (2017). The principle used in making estimates is based on microeconomics. This method requires that the company's market power on the difference in market price compared to marginal cost can be obtained. Researches that have been carried out by applying this method to analyze the banking industry shows that there should not be a perfectly competitive market system in the banking world.

Shaffer (1982) examined the banking industry in Canada by using data obtained in succession in time for demand data in the banking sector and 
performed calculations by estimating the average level of competition during the observation period Bikker and Haaf (2002) Bikker, and Haaf (2002) implemented the same method for the banking industry in European countries. However, the estimated data use time-series data to obtain a value that will produce an average level of competition over a certain period.

The use of panel data on financial statements owned by banks will estimate the average level of competition as a whole and can even be used as a tool to evaluate each year. Angelini and Cetorelli (2003) in Usman (2017) used this method for banking in Italy, Uchida and Tsutsui 2005) applied it to Japanese banking, and Kubo (2006) in Usman (2017) for banking in Thailand. The results of his research estimate the level of competition in the Indonesian banking industry using panel data during the period 1999-2006.

The Bresnahan-Lau model is popularly used for empirical research on banking competition, as has been stated by Shaffer (1982). He was the first to apply the BL model in the banking industry. Shaffer estimates banking in New York using the Breshanan-Lau model (1982) with 1989 data and finds monopolistic competition behavior.

Another study was conducted by Nathan and Neave (1989), which examined banking competition in Canada. This research on banking in Canada is consistent with Shaffer's research using the Bresnahan methodology, which rejects the monopoly power hypothesis. They found perfect competition behavior for 1982 and monopolistic competition for 1983-1984.

Competition testing in the banking industry using the BL method for developing countries is still relatively limited. Gelos and Roldos (2002) analyzed some banking markets using the BL methodology for banking in several developing countries in 1994-1999. They found that all banking markets in a sample of eight countries in Europe and Latin America were competitive despite increasing concentration levels. They concluded that the

Economica: Jurnal Ekonomi Islam - Volume 11, Nomor 2 (2020) 
reduced barriers to entry, such as the increasing entry of foreign banks, have increased competitive pressures.

Research on competition and contestability in Trinidad and Tobago was also conducted by Rambarran (2000) using data from 1990-1998. The BL model test rejected the monopoly and perfect competition hypotheses, but the banking sector in that country was in a condition of monopolistic competition.

Using the same methodology, Yildirim and Philippatos (2007) analyzed the banking system in Eastern Europe and Central Europe from 1992-1999. According to the study, the banking system cannot be categorized as perfect competition or monopolistic except in Latvia, Macedonia, and Lithuania. In general, they concluded that large banks in developing countries are relatively more competitive than small banks.

Bikker and Haaf (2002) used the Bresnahan methodology and the P-R methodology to analyze banking competition in 17 European countries and seven non-European countries, i.e., the United States, Japan, Korea, New Zealand, and Canada. They did not accept the hypothesis of perfect competition or the perfect cartel system (collusive oligopoly) of all markets. However, the study cannot deny the ideal collusion imposed on the Australian and Greek banking markets when conducting a minor market analysis. He found that smaller banks usually operate less competitively than banks on a national or international scale. Further findings that, in general, the level of competition becomes less intense for non-European countries. In 2002, using the BL model, Bikker and Haaf again tested competitive conditions in 23 countries. For all countries, the results were consistent with monopoly competition. In this study, Bikker and Haaf also attempted to relate competition as measured by $\mathrm{H}$-stat to market structure. They found that competition was negatively associated with concentration but not significantly. 
Claessens and Laeven (2003) in Kasri and Iman (2010) conducted a competition test by linking competition between a country's banking sector with structural indicators and financial system policies. The study used panel data (1994-2001) for 50 countries. Their findings were similar to Biker and Haaf's; each country experiences a low level of competition, as is the case in the United States. Further results identify the factors that explain the contestability of the banking sector between countries. They perform H-stat regression on variables including the presence of foreign banks, reduced entry restrictions, and low restriction activities. In all model specifications, contestability is positively related to concentration and negatively related to several banks.

Lee and Kim (2004) applied the latest BL model to the banking industry in Korea. The data used are the years 1999-2002. The banking crisis has prompted changes in the banking market structure in the country. After the crisis, the banking industry became more concentrated. There are two models. The first model uses interest receipts as the dependent variable.

In contrast, the second model uses the total acceptance variable as the independent variable. The two models yield different conclusions. In the first model, it is found that the monopoly power of banks increases after the crisis even though banks compete in monopolistic competition conditions both before and after the crisis. Meanwhile, in the second model, it was found that the market structure changed from monopolistic competition to monopoly after the crisis.

There are very few studies using the BL methodology for Sharia banking, among others, is Abdul Majid et al. (2007) in Kasri and Iman (2010). They studied 17 Malaysian Sharia banks between 2001 and 2005. For Sharia banking, modifications are made to the dependent variable. For example, if in the previous study (for conventional banks), the ratio of interest income to total assets was used for the dependent variable, then it was changed to total income to total assets obtained by banks.

Economica: Jurnal Ekonomi Islam - Volume 11, Nomor 2 (2020) 
It is based on the fact that Islamic banking does not charge interest in its activities. Therefore, the research results are that Sharia banking income is generated under conditions of monopolistic competition, and the assumption of oligopoly and monopoly competition is rejected. Furthermore, it is concluded that the competitive behavior of banks is not directly related to the number of banks operating in the market or the concentration of banks owned by them.

The latest study was conducted by Weill (2009) in Kasri and Iman (2010). In his study, Weill used the BL and SCP methodologies and tested the Sharia banking with the conventional banking system, using data from the conventional banking system and Sharia banking for countries that apply the dual banking system from 17 countries between 2000-2007. The sample countries for this study are Brunei, Bangladesh, Bahrain, Iran, Tunisia, Brunei, Indonesia, Qatar, Iran, Jordan, the United Arab Emirates (UAE), Malaysia, Mauritania, Pakistan, Saudi Arabia, Kuwait, Sudan, Turkey, and Yemen. The result of the study is that there is no significant difference in market power between Sharia banking and conventional banking. Meanwhile, the results of the P-R methodology show that the $\mathrm{H}$-stat value for the Sharia banking system is higher than the conventional banking system. However, the value is only significant for the 2005 and 2007 studies.

A study in Indonesia using the BL method was carried out by Lubis (2012). The object of study includes national banking in Indonesia from 19902004. The results show that the level of competition in the credit market for the banking industry in Indonesia is still relatively high. In other words, the market power is still low. 
Determinant Market Power of Sharia ...

Table 1. Market Power Research Results Using the Bresnahan-Lau Model

\begin{tabular}{|c|c|c|c|}
\hline Researchers & Period & Research samples & Results \\
\hline Shaffer (1982) & 1979 & $\begin{array}{l}\text { United State (New } \\
\text { York) }\end{array}$ & MC \\
\hline $\begin{array}{l}\text { Nathan dan Naïve } \\
\text { (1989) }\end{array}$ & 1982-1984 & Canada & MC $(1983,1984) ;$ PC (1982) \\
\hline Gelos dan Roldos (2002) & 1994-1999 & $\begin{array}{l}8 \text { European and Latin } \\
\text { American Countries }\end{array}$ & $\begin{array}{l}\text { MC for all Countries except } \\
\text { Argentina and Hungary } \\
\text { approaching PC }\end{array}$ \\
\hline Rambarran (2000) & 1990-1998 & Trinidad Tobago & MC \\
\hline $\begin{array}{l}\text { Philipatos dan Yildrim } \\
\text { (2002) }\end{array}$ & 1992-1999 & $\begin{array}{l}\text { Eastern Europe and } \\
\text { Central Europe }\end{array}$ & $\begin{array}{l}\text { MC (Lithuania, Macedonia); PC } \\
\text { (Latvia); neither (other countries) }\end{array}$ \\
\hline $\begin{array}{l}\text { Claessens dan Laeven } \\
\text { (2003) }\end{array}$ & 1994-2001 & $\begin{array}{l}50 \text { industrialized and } \\
\text { developing countries }\end{array}$ & $\begin{array}{l}\text { MC (big countries tend to have } \\
\text { less competition) }\end{array}$ \\
\hline Kim dan Chun (2004) & 1999-2002 & South Korea & $\begin{array}{l}\text { Changes in the market structure } \\
\text { after the banking crisis }\end{array}$ \\
\hline Weill (2009) & $2000-2007$ & $\begin{array}{l}17 \text { countries that } \\
\text { operate dual banking } \\
\text { systems }\end{array}$ & $\begin{array}{l}\text { MC for both Sharia and } \\
\text { conventional banking }\end{array}$ \\
\hline $\begin{array}{l}\text { Andi Fahmi Lubis } \\
\text { (2012) }\end{array}$ & $1990-2004$ & Indonesia & $\begin{array}{l}\text { There is Market Power (tends to } \\
\text { be low) }\end{array}$ \\
\hline
\end{tabular}

$\mathrm{PC}=$ Perfect Competition; $\mathrm{MC}=$ Monopolistic Competition

\section{Relationship between variables}

\section{Effect of equivalent rate (ER) and SBIS on market power}

Profit-Sharing/Return has a negative and significant relationship with the demand for financing. It means that the higher the spread on Profit Sharing/Financing will reflect the more expensive costs, resulting in a decrease in the amount of financing. On the other hand, the lower the spread over Profit Sharing/Financing will reflect lower costs and increase the financing amount. This condition reflects that the current profitsharing/financing spread is still high and is a consideration for the business world, especially in applying for financing to Sharia (Harmanta and Ekananda 2005).

Economica: Jurnal Ekonomi Islam - Volume 11, Nomor 2 (2020) 


\section{The influence of number of branch offices on market power}

The number of bank offices $(\mathrm{N})$ will be positively correlated with the amount of financing. This condition allows the public to have easier access to banking. Like the balance model described by Manurung and Haymans (2013), the balance model of banks in Indonesia is based on the condition of banking financing and deposit behavior and is determined by the rate of profit-sharing on deposits, the rate of profit-sharing on financing, and gross domestic income, the response of financing managed by banks to the rate of profit-sharing on deposits, the level of profit-sharing of financing, as well as the gross domestic product obtained is in accordance with theoretical expectations. While the significance of the coefficient on banking financing explains that the market structure of banking financing in Indonesia has a monopolistic or oligopolistic tendency, meaning that deposit responses can occur in banks to the elasticity of deposit demand and the intensity of competition as well as the number of Sharia bank branch offices.

\section{Effect of GDP on market power}

Gross Domestic Product (GDP) has a unidirectional (positive) and significant relationship to financing. It means that increased economic growth will have an impact on increasing the amount of financing. On the contrary, an economic condition that is always weak (recession) will impact the amount of financing, which tends to decrease. This finding supports the reason for using this variable which acts as an essential proxy for market power (Harmanta and Ekananda 2005)

\section{Effect of inflation on market power}

The increase in inflation causes people reluctant to do financing because credit interest rates have increased, so financing or credit demand has decreased (Harmanta and Ekananda 2005). In fact, what happens in the field, most Sharia banks refer to the deposit interest rate prevailing in conventional 
banks as a benchmark for the desired profit margin (spread) (Romansyah 2009).

\section{Methods}

This research is explanatory research that uses a quantitative approach. Secondary data include one dependent variable, namely Market Power (MP), with five independent variables, namely Equivalent Rate (ER), 3-month Bank Indonesia Syariah Certificates (SBIS3), Number of Branches (CAB), Gross Domestic Product (GDP), Inflation (INF), and one control variable, namely the historical aspect (MPt-1) using time series data on the annual financial statements of Bank Syariah Mega Indonesia (BSMI), Bank Syariah Mandiri (BSM), and Bank Muamalat Indonesia (BMI), covering the period from 2009 to 2017, with the population used by all Sharia banking in Indonesia. Samplings were obtained through the purposive sampling method.

The variables used in this study are Dependent Variable Total Financing (MP), Independent Variable Equivalent Rate (ER). Variable 3-month Bank Indonesia Syariah Certificates (SBIS3), Number of Branches (CAB), and Gross Domestic Product (GDP) as community income indicators, Variable inflation (INF). The control variable is the quantity of financing in the previous year (MPt-1) with an equation model approach:

$$
M P_{i t}=\beta_{0}+\beta_{1} \mathrm{ER}_{i t}+\beta_{2} \mathrm{SBIS}_{i t}+\beta_{3} \mathrm{CAB}_{i t}+\beta_{4} \mathrm{PDB}_{i t}+\beta_{5} I N F_{i t}+\beta_{6} M P_{i, t-1}+\mu_{i t}+\eta_{i}
$$

\section{Explanation:}

i : : bank-specific index.

$t \quad$ : index for the year.

ER : the ratio of the indication of the level of profit-sharing obtained by the customer. 
SBIS3 : ratio of 3 months SBIS reward value.

$\mathrm{CAB}$ : the number of branches.

PDB :: gross domestic product.

INF : Inflation

MP-1 : MP-1 : lag variable from Y, which is used to explain historical aspects.

$\mu_{\mathrm{it}} \quad$ : unobserved specific effect.

$\eta_{1} \quad$ : random error.

Theoretical framework

Figure 1. Theoretical Thinking Framework

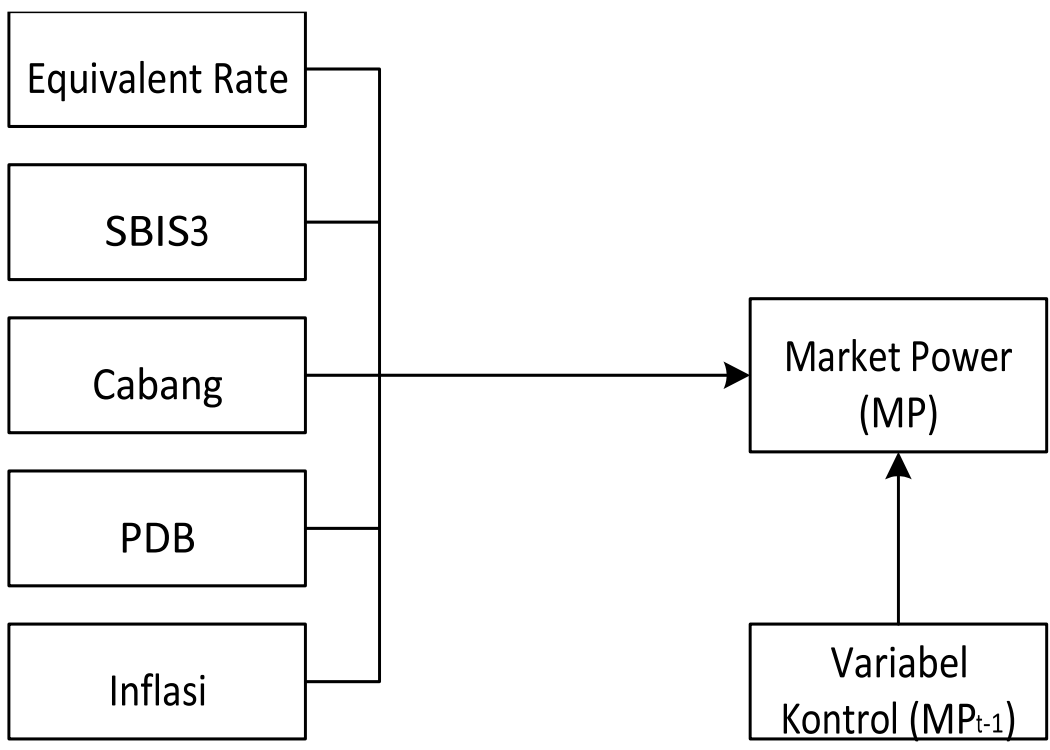

Source: developed for research in 2018. 
Determinant Market Power of Sharia ...

\section{Research hypothesis}

H1: It is assumed that the Equivalent Rate (ER) affects Sharia banking market power.

H2: It is assumed that 3-month Bank Indonesia Syariah Certificates (SBIS3) affect the MP of Sharia banking.

H3: It is assumed that the number of branches (CAB) affects Sharia banking market power.

H4: It is assumed that the Gross Domestic Product (GDP) affects the Market Power of Sharia banking.

H5: It is assumed that Inflation (INF) affects the MR PBS.

\section{Result and discussion}

\section{Descriptive statistics of research variables}

The data used in this study are 96 data with details from the third quarter data of Sharia Commercial Banks (BUS) in Indonesia during the study period of 8 years. The data for the lowest total financing ( $\mathrm{min}$ ) is Rp. 13,324,000,000 and the highest (max) is Rp. 14,805,385,000,000, the average (mean) total financing is Rp. 4,082,788,000,000, and the standard deviation is Rp. $3,735,622,000,000$. .

\section{Market power test}

Market Power testing is done by interacting the Equivalent Rate (ER) variable with the Gross Domestic Product (GDP) variable. Market Power Testing in this study was conducted by Interaction Testing. If the statistical $\mathrm{z}$ value is below 5 percent $(p<0.05)$, it can be said that there is an interaction effect between the Equivalent Rate (ER) variable and GDP, which means that there is Market Power.

Economica: Jurnal Ekonomi Islam - Volume 11, Nomor 2 (2020) https://journal.walisongo.ac.id/index.php/economica 
Table 2. Market Power Test Results

\begin{tabular}{r|rrrrrr}
\hline totpem & Coef. & Std. Err. & z & P $>|z|$ & [95\% Conf. Interval] \\
\hline totpem & & & & & & \\
L3. & 1.10815 & .026982 & 41.07 & 0.000 & 1.055266 & 1.161034 \\
& & & & & & \\
er & -20.09135 & 4.822401 & -4.17 & 0.000 & -29.54308 & -10.63962 \\
pdb & 5.935599 & 1.358206 & 4.37 & 0.000 & 3.273564 & 8.597635 \\
er_pdb & 3.653737 & .8362522 & 4.37 & 0.000 & 2.014713 & 5.292762 \\
_cons & -34.11933 & 7.805422 & -4.37 & 0.000 & -49.41768 & -18.82099 \\
\hline
\end{tabular}

Source: Processed secondary data, 2018.

Based on Table 2, the value of the interaction variable has a coefficient value of 3.653 with a prob of $0.000(\mathrm{p}<0.05)$. Therefore, because of the significant probability value, it can be said that there is Market Power in this study.

\section{Effect of variables on market power}

\section{Market power last year (historical aspect)}

It is conducted to determine the effect of Market Power last year (MPit-1). The regression coefficient is 1.048 with a significance level of $0.000(\mathrm{p}<0.05)$. It means that last year's Market Power variable significantly influences the Sharia banking market power this year.

\section{Equivalent rate (ER)}

The ER regression coefficient is -7.042 with a significance level of 0.000 $(\mathrm{p}<0.05)$. It shows that the ER aspect has a significant effect on total financing. So it can be concluded that the hypothesis that ER has a significant impact on Market Power cannot be rejected or accepted. 


\section{3-month bank indonesia syariah certificates (SBIS3)}

The SBIS3 regression coefficient is 2.194 with a significance level of 0.022 $(\mathrm{p}<0.05)$. It shows that the SBIS3 aspect has a significant influence on the total financing. These results are following the hypothesis that SBIS3 has a significant effect on Market Power. Thus, it can be concluded that the hypothesis which states that SBIS3 has a significant effect on Market Power cannot be rejected or accepted.

\section{Number of branch offices}

The regression coefficient for the number of branch offices is -0.002 with a significance level of $0.046(\mathrm{p}<0.05)$. Thus, it shows that the number of branch offices has a significant influence on Market Power. Thus, it can be concluded that the hypothesis which states that the number of branch offices has a significant effect on Market Power cannot be rejected or accepted.

\section{Gross Domestic Product (GDP)}

The GDP regression coefficient is 0.167 with a significance level of 0.001 $(\mathrm{p}<0.05)$. It shows that the GDP aspect has a significant influence on Market Power. Thus, it can be concluded that the hypothesis that GDP has a significant effect on Market Power cannot be rejected or accepted.

\section{Inflation}

The inflation regression coefficient is 17.855 , with a significance level of 0.003. Therefore, it shows that the inflation aspect has a significant influence on Market Power. Thus, it can be concluded that the hypothesis which states that inflation has a significant effect on Market Power cannot be rejected or accepted. 


\section{Conclusion}

Examining the market power of Sharia banking in Indonesia is carried out using the Bresnahan Lau oligopoly model. The study results indicate that there is market power in the Sharia banking industry in Indonesia, as evidenced by the significance level of the ER and GDP interaction test of 0.000. In addition, the competitive behavior of Islamic commercial banks in distributing financing is relatively high. Thus, Sharia banking can influence prices and show the level of competition in Indonesia's banking market.

Equivalent Rate (ER) has a significant effect on total financing. The regression coefficient is -7.042 with a probability level of 0.000 . Thus, the first hypothesis, which states that ER has a significant effect on market power, cannot be rejected or accepted.

3-month Bank Indonesia Syariah Certificate (SBIS3) has a significant effect on total financing. The regression coefficient is 2.194 with a probability level of 0.022 . Thus, the second hypothesis, which states that SBIS3 has a significant effect on market power, cannot be rejected or accepted.

The number of branch offices has a significant effect on market power. The regression coefficient is -0.002 with a probability level of 0.046 . Thus, the third hypothesis, which states that the number of branch offices significantly affects total financing, cannot be rejected or accepted.

Gross Domestic Product (GDP) has a significant effect on total financing. The regression coefficient is 0.167 with a probability level of 0.001 . Thus, the fourth hypothesis, which states that GDP significantly affects total financing, cannot be rejected or accepted.

Inflation has a significant effect on total financing. The regression coefficient is 17.8 , with a probability level of 0.003 . Thus, the fifth hypothesis, which states that inflation significantly affects total financing, cannot be rejected or accepted. 
This study only takes the variables of Equivalent Rate (ER), Bank Indonesia Syariah Certificate (SBIS3), number of branch offices, Gross Domestic Product (GDP), and inflation. It is assumed that many other factors affect the total financing, such as social, economic, cultural, and others.

This research only covers the period after the crisis (after the economy improved), starting from 2009 to 2017. Thus, it is impossible to see differences in market power before or during the crisis (1998). So that when there is a monetary crisis in future conditions, we are able to see the strength of the relationship in influencing market power in the context of formulating more appropriate policies.

The objects in this study include only 3 Sharia Commercial Banks (BUS) in Indonesia, namely Bank Muamalat Indonesia (BMI), Bank Syariah Mandiri (BSM), and Bank Syariah Mega Indonesia (BSMI). It would be better if a study was conducted on all Sharia banking in Indonesia (BUS, UUS, and BPRS) to be able to better see the market power of Sharia banking in Indonesia as a whole or by comparing Sharia banks and conventional banks to see the market power position of Sharia banking compared to conventional banking.

\section{References}

Antonio, Muhammad Syafi. 2001. Bank Syariah: Dari Teori Ke Praktek Islamic Banking. Gema Insani. http://onesearch.id/Record/IOS2726.slims109756.

Bank Indonesia. 2002. Cetak Biru Perbankan Syariah 2002-2005. Jakarta: Bank Indonesia.

Bikker, Jacob, and Katharina Haaf. 2002. "Measures of Competition and Concentration in the Banking Industry: A Review of the Literature." Economic \& Financial Modelling 9 (2): 53-98.

Chapra, M. Umer. 2003. Islam and the Economics Challenge. USA: International Institute of Islamic Thought.

Church, Jeffrey., and Roger. Ware. 2000. Industrial Organization. Singapore: Mc.Graw Hill Comp. Inc.

Economica: Jurnal Ekonomi Islam - Volume 11, Nomor 2 (2020) 
Demirel, Onur, and Selim Adem Hatirli. 2017. "Measuring the Performance of the Banking Sector in Turkey." Journal of Academic Researches and Studies 9 (16): 20-34.

Gelos, Gaston., and Jorge E. Roldos. 2002. "Consolidation and Market Structure in Emerging Market Banking Systems." IMF Working Paper No. 2.

Greenwald, A. G., and A. R. Pratkanis. 1984. Handbook of Social Cognition. Hillsdale NJ: Erlbaum.

Harmanta, Harmanta, and Dr. Mahyus Ekananda. 2005. "Disintermediasi Fungsi Perbankan Di Indonesia Pasca Krisis 1997: Faktor Permintaan Atau Penawaran Kredit, Sebuah Pendekatan Dengan Model Disequilibrium." Buletin Ekonomi Moneter Dan Perbankan 8 (1): 51-78. https://doi.org/10.21098/bemp.v8i1.128.

Kasri, Rahmatina A., and Nur. Iman. 2010. "Analisis Persaingan Perbankan Syariah Indonesia: Aplikasi Model Panzar-Rosse." Jurnal Ekonomi Dan Pembangunan Indonesia XI (1): 1-20.

Kim, Jae-II, Hee Chun Lee, and Hae Joo Kim. 2004. "Factors Affecting Online Search Intention and Online Purchase Intention." Seoul Journal of Business 10 (2): 27-48.

Lubis, Andi Fahmi. 2012. "Market Power Perbankan Indonesia." Buletin Ekonomi Moneter Dan Perbankan 14 (3): 235-56.

Manurung, Manurung, and Adler. Haymans. 2013. Initial Public Offering (IPO) Konsep, Teori Dan Proses. Jakarta: PT Adler Manurung Press.

Nathan, A., and E.H. Neave. 1989. "Competition and Contestability in Canada's Financial System : Empirical Result." Canadian Journal of Economic 3 (1).

Pindyick, Robert S., and Daniel L. Rubinfeld. 2013. Microeconomics. U.S.A: Microsoft Corporation.

Prasetyo, P. Eko. 2007. "Hubungan Struktur Pasar Dan Perilaku Pasar Serta Pengaruhnya Terhadap Kinerja Pasar." Jurnal Ekonomi Pembangunan 12 (3): 111-22.

Romansyah, Dadang. 2009. "Penentuan Rate Bagi Hasil Deposito Mudharabah Bank Syariah Di Indonesia: Analisis Teori Dan Praktik." In National Seminar on Iskamic Banking Research.

Samuelson, Paul Anthony, and William Dawbney Nordhaus. 2009. Economics. New York: McGraw-Hill. 
Shaffer, S. 1982. "Structural Test for Competition in Financial Markets; Bank Structure and Competition." In Bank Structure and Competition, Conference Proccedings. https://doi.org/10.1145/3132847.3132886.

Theis, Richard. 2016. "Perbandingan Kinerja Keuangan Bank Umum Pemerintah Dan Bank Swasta Nasional ( Devisa ) Yang Go Publik Di Bei (Periode 2010-2014)." Jurnal Berkala Ilmiah Efisiensi 16 (01): 914-24.

Uchida, Hirofumi, and Yoshiro Tsutsui. 2005. "Has Competition in the Japanese Banking Sector Improved?" Journal of Banking and Finance 29 (2): 41939. https://doi.org/10.1016/j.jbankfin.2004.05.013.

Usman, Bahtiar. 2017. "Penetrasi Bank Asing Dan Pengaruhnya Terhadap Kompetisi Perbankan Yang Diukur Dengan Pendekatan Conjectural Variation Di Indonesia." Media Ekonomi 21 (1): 1. https://doi.org/10.25105/me.v21i1.790.

Yafie, Ali. 2003. Fiqih Perdagangan Bebas. Jakarta: Teraju.

Yildirim, H Semih, and George C Philippatos. 2007. "Competition and Contestability in Central and Eastern European Banking Markets." Managerial Finance 33 (3): $195-209$. https://doi.org/10.1108/03074350710718275. 
Muchamad Fauzi 